\title{
The wicked problem of tourism: economic benefits versus socio-cultural impacts
}

\author{
M. Odeh \\ Abu Dhabi University, UAE
}

\begin{abstract}
This paper is based on a research conducted regarding the local perceptions of tourism in Dubai. The purpose of the study was to investigate this issue, since it has been the subject of very little research. Dubai's status as a global tourism destination is raising concerns among the locals about the impacts of tourism on their culture. To verify these concerns, this study designed a questionnaire that was administered to Emaratis. Overall, respondents confirmed most concerns that tourism affects local culture negatively, but some areas were viewed positively by the respondents. Hence, the research showed that Emaratis have mixed feelings towards tourism: they understand its economic benefits but have feelings of resentment for its affect on their national culture and social identity. Keywords: socio-cultural impacts, tourism impacts, UAE, Dubai, Middle East.
\end{abstract}

\section{Introduction}

Tourism is one of the fastest growing industries in the world; it is promoted as a means of development and economic growth and governments worldwide are endorsing tourism development plans and spending billions in the process. The UAE is one of those countries, with Dubai as the forerunner closely followed by Abu Dhabi. Dubai occupies a land area of $3,885 \mathrm{~km}^{2}$, is the second largest emirate with a population of 1.422 million of which 1.073 million are male [1]. The primary tourist attractions are beaches, nightlife, shopping and luxury accommodations, with other upcoming attractions such as the US\$9.5 billion Dubailand project [2]. In 2007, Dubai had 5.42 million visitors [3] contributing to $22.6 \%$ of the economy [4].

Of primary interest in this study is the myriad of views that tourism scholars across the board have shared on the impacts of western-dominated tourism on 
indigenous cultures in the developing world. Quite interesting is that the various impacts discussed in the literature fall into either the good or bad category and very few in the 'undecided' category, making any consensus or conclusion improbable in the least. For example, while there is hardly any argument against the economic benefits of tourism from an ideal stance, from a more practical stance, there are questions about the equity of the benefits or dividends of tourism [5]. There are also serious contentions about how tourism impacts local cultures, customs and traditions, especially in culturally conservative communities. Many of the undesirable impacts have been viewed as causes of frictions or tension between tourists and hosts around the world, leading in some cases to strong anti-tourist sentiments [6-10].

The key to the socio-cultural impacts of tourism is manifested by the relationship between hosts and guests [6, 11-13]. Social and cross-cultural interactions will always occur in the tourism industry as the tourist encounter is simply a series of transactions between hosts and guests. Socio-cultural impacts are the outcome of different types of relationships that occur between the two as a result of their coming into contact [14]. Higgings-Desbiolles [7] notes that tourist behaviour is usually insensitive to local population sentiments based on the western notion of the 'Right to Travel' as opposed to privilege. The sociocultural and economic differences between the two parties lead to an unbalanced relationship between what she terms as 'the wretched' and 'the rich' [7]. Mowforth and Munt [6] note that in practice there is a limited chance of tourists and hosts to meet as equals and truly learn about each other. Rather, the relationship that develops is more of a master-servant one. They too note the unbalanced rapport that corresponds to postmodern unequal power relations [6]. There are also indirect encounters, clashes that arise due to conflicting interests. Examples are: tourists' demand for 'authentic' resident lifestyles (meaning 'traditional', 'old' and 'primitive') that conflicts with residents' need for modernisation and sophisticated services [15]; relocating residents to provide for tourism facilities [16]; residents' need for privacy and tourists' demand for 'observing' [10]. The presence of sizeable numbers of tourists from different cultures, will therefore inevitably have bearing on the societies they visit [6].

Economic impact studies have had a tendency to focus on the benefits that accumulate in a tourist destination and give little consideration to the costs [19]. The reasons for this are mainly two. First, many of the benefits, such as increased returns and employment, are tangible and easy to measure while costs, such as noise, congestion, and pollution, are elusive and difficult to measure economically. Second, economic impact studies are often commissioned by tourism advocates to back tourism policies [5]. Tourism is certainly not bad in itself, but whether it always plays a positive role in developing countries must be questioned $[5,8]$. The question is worth bringing up at a time when most Arab states, the UAE being no exception, are pinning their hopes on tourism and giving it priority in development programmes.

The perceived social and cultural impacts of tourism refer to the ways in which tourism is seen to contribute to changes in value systems, individual behaviour, family relations, collective lifestyles, safety levels, moral conduct, 
creative expressions, traditional ceremonies, and community organisations [18]. Tosun [14] suggests that the perceived socio-cultural impacts on destination communities can be classified into two categories. The first is the impact in connection to the character of the destination; this includes the perceived impacts that affect changes in values, attitudes, or behaviour of hosts that result from observing tourists. The second is the social impacts on infrastructure development and their effects on the local resources such as pressure on facilities, local versus imported labour, local language and lifestyle changes [14].

Factors that have an influence on residents' perceptions and attitudes towards tourism include: type and extent of tourist-host interaction, importance of the industry, level of tourism development, dependence on the industry, and extent of tourism concentration in the area as well as resident-specific factors such as native-born status, length or residence in the community, whether or not he works in the tourism industry and distance of residence from the central tourist area [18-22]. According to other studies, intervening variables, such as participation in formal tourism education and participation in outdoor recreation, are believed to result in perceptual differences among residents [23].

Jafari [5] gives weight to the demonstration effect that is observed in the destination's residents both economically and socially. He argues that in addition to increased consumption, the demonstration effect influences lifestyle, behaviour, heritage and ideology changes in the host community. As a result, the demonstration effect can contribute to the birth of an unbalanced and premature imitation of modernization (which he terms the 'marginal man and his world') in the developing countries and add to the social dualism which plagues them [5]. However, Fisher [24] contests this effect, claiming that there is something overtly patronising about the implicit assumption that the cultures of host societies are so weak that they need protecting from contact with tourism [24].

Jafari [5] also stresses that xenophobia can be an important result of rapid tourism development, especially in the context of unbalanced relationships of power and wealth. When local culture, tradition, heritage and religion are used as 'commodities', that are 'consumed by a group of foreigners or strangers called tourists' while they are highly respected by nationals, this would especially be irritating $[5,25]$. He also argues that the travel industry runs the risk of creating an enclave in which affluent foreigners are catered to and use resources which are not available to the mass of the domestic peoples $[5,6,25]$, this enclave, Jafari [5] adds, is fertile ground for xenophobia. Daher [8] agrees and gives the example of Dubai as a 'playscape' which is actually a group of simple gated communities with practices of inclusion and exclusion.

On the other side of the spectrum, many believe tourism can have favourable impacts on developing countries. By bringing people of different cultures together, tourism provides a direct contact between them and thus serves as a powerful means of diffusion of world cultures. It provides an opportunity for friendly and peaceful dialogue leading to better understanding between people and nations. It can build bridges and create friendship between nations leading to establishing peace $[22,26]$. Some [27] even believe that there are socio-cultural benefits to tourism. These include learning, awareness, appreciation, family 
bonding, community pride, a firmer sense of ethnic identity, increased understanding and tolerance of others, and stronger cultural identity. Sociocultural benefits can be realized both by tourists and host communities through interrelations that foster cross-cultural communication [27]. Residents can achieve these benefits in one of two ways: their exposure to culture results in understanding and tolerance, and them presenting their culture strengthens their identity, pride, cohesion and support [22, 27].

Looking at the issue from a regional side, it seems that a predominant trait of tourism policies in Middle Eastern countries is the disparity between policies and strategies on one side, and realities and implementation on the other, which poses a threat to the success of tourism $[8,28]$. Governments tend to assume a modernist developmental paradigm centring on economic growth and biased towards the formal tourism sector despite its high initial cost and high leakage, while the informal sector is excluded from national policies [5, 8]. Henderson [29] notes the opportunity costs and financial risks associated with the UAE Government's approach to tourism development. She also criticizes the partiality of officials and developers for the ostentatious, which is manifest in Dubai's extraordinary projects and argues that Dubai should be promoted as more than just a beach tourism and shopping venue, but one that has unique natural and cultural heritage attractions [29].

However, Orbasli [15] disagrees. She argues that in Dubai vernacular heritage is being rejuvenated as the tourism base is expanded. Tourism promotion includes cultural excursions to traditional wind tower houses that have in fact been rebuilt or reinstated partly in response to the tourism potential and describes the Bastakia district as 'a historic resource of potential value to tourism'. She argues that it is perceived that the restored area will complement other types of tourist attractions. Nevertheless, the area is being resorted as museum. However, one of the most important characteristics of the Islamic city was that it was a living city and when everyday life is replaced by land commercialism and showcase restoration the very essence of the city is lost [15]. She notes the limited tourist interest in the Bastakia district of Dubai and questions the authenticity.

If any conclusion can thus be drawn at this point, it must be that authors in the field hold widely varying views concerning whether or not tourism offers benefits to host communities [22, 23, 25, 30]; nonetheless there seems to be a wide spectrum of issues related to tourism in third world countries in general including the Middle East.

\section{Methodology}

The data used for this study came from a combination of primary and secondary sources. The primary source was a survey conducted using a questionnaire appropriate for investigating people's perceptions. The secondary sources include a variety of scholarly, media and government publications that contained data pertinent for this study. For the survey, a questionnaire was designed and administered electronically to 230 Emaratis employed by Dubai World in the 
spring of 2008. A total of 108 valid questionnaires were returned, resulting in a response rate of $47 \%$. The cohort of Emaratis surveyed was selected for the pragmatic expediencies of time and cost, but most importantly in order to ensure a decent response rate to the survey. The research survey culture in the UAE is yet in its rudimentary stages, and it takes the type of connection that the researcher has with the employer of the Emaratis surveyed to get the desired response to the research survey.

The data collected through the survey was analyzed using basic descriptive techniques. First, the questionnaire results were calculated by using percentages to determine the frequency of responses to each of the questions asked. The questions were conceptually clustered based on the theme, intent or purpose of each question. Then, they were compared with regards to demographics to find the differences in responses of each demographic category of the respondents.

This study has several limitations; first, the unusual demographic composition of the UAE may have an effect on the views of Emaratis towards tourism. It may also make it difficult for the locals to distinguish between a tourist and an expatriate. Second, the survey was taken during the last economic boom in Dubai, the impacts of this boom are two-fold: on one side it polarises the economic benefits, on the other it causes increased numbers of tourists and expatriates. Third, the survey was limited to people working with an organisation that has an indirect relation to tourism, as one of its major subsidiaries, Nakheel, is a major developer that benefits from the rapid increase in tourism.

\section{Results and discussion}

A relative majority of the respondents reside in Dubai (47\%), distantly followed by Abu Dhabi (16\%), then Sharjah (13\%). Most have been tourists themselves, which should give them some critical perspectives. $78 \%$ have visited the Gulf region, $47 \%$ have been to other Arab countries, and 31\% have been to Turkey and Iran. $42 \%$ have been to Europe, $15.4 \%$ to North America and approximately $4 \%$ to Australia or New Zealand. In addition, a considerable number has travelled to South Asia (32\%) and East or Southeast Asia (36.5\%). The absolute majority $(74 \%)$ of the respondents were between 21 and 35 years old, $11.5 \%$ between 36 and 49 years, and 14.5\% 20 years or less. Most surprising was that no respondent reported being fifty years or older. With regards to the education level, a small majority (58.65\%) have a bachelor's degree or higher and $2 \%$ were part time students. $58 \%$ of the respondents reported being unmarried and $62 \%$ had no children. All the respondents but one practice the Muslim faith.

\subsection{Results of the survey}

At the heart of this research is the issue of the perception of tourism's impacts on local Emarati culture by Emaratis themselves. Therefore, some propositions were made pointedly to the respondents, and they were to state their level of agreement or disagreement with the propositions. It is important to state that, in order to transcend the generic or nebulous notion and interpretation of culture, 
Table 1: $\quad$ Emaratis' perceptions of the impacts on culture.

\begin{tabular}{|c|c|c|c|c|}
\hline Statement & Agree & Disagree & Neutral & $\begin{array}{l}\text { Don't } \\
\text { know }\end{array}$ \\
\hline \multicolumn{5}{|l|}{ General attitude } \\
\hline $\begin{array}{l}\text { I find that tourism and local culture do } \\
\text { not mix or agree }\end{array}$ & $21.15 \%$ & $70.19 \%$ & $2.88 \%$ & $5.77 \%$ \\
\hline $\begin{array}{l}\text { Overall, tourism has more negative than } \\
\text { positive impacts on Emarati culture }\end{array}$ & $58.65 \%$ & $23.08 \%$ & $8.65 \%$ & $9.62 \%$ \\
\hline $\begin{array}{l}\text { I do not regularly go with my family to } \\
\text { beaches that tourists go to }\end{array}$ & $83.65 \%$ & $9.62 \%$ & $3.85 \%$ & $2.88 \%$ \\
\hline \multicolumn{5}{|l|}{ Learning Tool } \\
\hline $\begin{array}{l}\text { Tourism does not teach Emaratis about } \\
\text { other cultures coming to the country }\end{array}$ & $25.96 \%$ & $57.69 \%$ & $11.54 \%$ & $4.81 \%$ \\
\hline $\begin{array}{l}\text { Overall, tourism in Dubai is only for } \\
\text { business profit, not cultural exposure }\end{array}$ & $54.81 \%$ & $28.85 \%$ & $9.62 \%$ & $6.73 \%$ \\
\hline $\begin{array}{l}\text { Tourism does not teach Emaratis to be } \\
\text { more culturally tolerant }\end{array}$ & $29.81 \%$ & $53.85 \%$ & $6.73 \%$ & $9.62 \%$ \\
\hline \multicolumn{5}{|l|}{ Bad Influence } \\
\hline $\begin{array}{l}\text { Tourism affects the Arabic language } \\
\text { negatively }\end{array}$ & $68.27 \%$ & $19.23 \%$ & $10.58 \%$ & $1.92 \%$ \\
\hline $\begin{array}{l}\text { Allowing tourists to drink alcohol tempts } \\
\text { Emaratis to drink as well }\end{array}$ & $83.65 \%$ & $10.58 \%$ & $3.85 \%$ & $1.92 \%$ \\
\hline $\begin{array}{l}\text { Young Emaratis tend to imitate some } \\
\text { tourist behaviours }\end{array}$ & $62.50 \%$ & $25.96 \%$ & $8.65 \%$ & $2.88 \%$ \\
\hline
\end{tabular}

some indicators were inserted in some of the propositions to enable the respondents to focus on what the researcher believes are specific aspects of Emarati culture. These propositions, the cultural indicators and the responses of the survey respondents are shown in Table 1.

Two crucial observations from Table 1 are worth mentioning. First, there is the view that tourism as it is, is not working well with the Emarati culture. Despite this, only $21 \%$ of Emaratis do not believe that tourism and the local culture do not agree. This implies that the main objection is to the way tourism is applied; this view is enforced by the majority of respondents that believe the government should intervene to protect the culture as would be shown in Table 3. Second, there seems to be very strong concern about the impacts of tourism on the social behaviours of young Emaratis as shown by the strong agreement with the propositions that link tourism to the tendency for youths to drink alcohol and imitate some behaviour of tourists. When it comes to bad influence, the perceptions are generally highly negative.

In order to probe into what specifically it is about tourism and tourists that irks Emaratis and/or causes them to be concerned, the propositions in Table 2 were made and the respondents were asked to express their stand on each.

There is acknowledgement by $66 \%$ of the respondents that most tourists do not understand Emarati culture. It is understandable, therefore, why there would be occasional frictions. The cultural ignorance perhaps shows why only $45 \%$ of the survey respondents agree that tourists do not respect Emarati culture. 
Table 2: $\quad$ Tourist attitudes and behaviour.

\begin{tabular}{ccccc} 
Question & Agree & Disagree & Neither & $\begin{array}{c}\text { Don't } \\
\text { know }\end{array}$ \\
\hline \hline General Behaviour & & & & \\
\hline $\begin{array}{c}\text { Tourists should be given strict dress } \\
\text { codes to respect Emarati culture }\end{array}$ & $78.85 \%$ & $13.46 \%$ & $3.85 \%$ & $3.85 \%$ \\
\hline $\begin{array}{c}\text { Tourists should not be allowed to drink } \\
\text { alcohol in Dubai }\end{array}$ & $84.62 \%$ & $8.65 \%$ & $4.81 \%$ & $1.92 \%$ \\
\hline $\begin{array}{c}\text { Most tourists are rude and disrespectful } \\
\text { Tourist Attitudes }\end{array}$ & $50.96 \%$ & $25.96 \%$ & $8.65 \%$ & $14.42 \%$ \\
\hline $\begin{array}{c}\text { Most tourists do not even understand } \\
\text { Emarati culture and beliefs }\end{array}$ & $66.35 \%$ & $15.38 \%$ & $10.58 \%$ & $7.69 \%$ \\
\hline $\begin{array}{c}\text { Most tourists do not respect Emarati } \\
\text { culture and beliefs }\end{array}$ & $45.19 \%$ & $28.85 \%$ & $15.38 \%$ & $10.58 \%$ \\
\hline
\end{tabular}

Table 3: $\quad$ Economic impacts.

\begin{tabular}{ccccc} 
Question & Agree & Disagree & Neither & $\begin{array}{c}\text { Don't } \\
\text { know }\end{array}$ \\
\hline \hline $\begin{array}{c}\text { Dependence on Economy } \\
\text { The economy of Dubai is too dependent } \\
\text { on tourism }\end{array}$ & $60.58 \%$ & $25.96 \%$ & $6.73 \%$ & $6.73 \%$ \\
$\begin{array}{c}\text { If it had not been for tourism, Dubai } \\
\text { would not have developed and increased } \\
\text { in urbanization and prosperity }\end{array}$ & $43.27 \%$ & $46.15 \%$ & $6.73 \%$ & $3.85 \%$ \\
\hline $\begin{array}{c}\text { Without tourism, the economy of Dubai } \\
\text { will be very weak }\end{array}$ & $35.58 \%$ & $50.96 \%$ & $7.69 \%$ & $5.77 \%$ \\
\hline $\begin{array}{c}\text { Equitability and Leakage } \\
\text { Government benefits more from tourism } \\
\text { than private businesses }\end{array}$ & $43.27 \%$ & $18.27 \%$ & $12.50 \%$ & $25.96 \%$ \\
\hline $\begin{array}{c}\text { Expatriates benefit more from tourism } \\
\text { than Emaratis }\end{array}$ & $54.81 \%$ & $22.12 \%$ & $6.73 \%$ & $16.35 \%$ \\
\hline
\end{tabular}

Respondents seem to feel that alcohol consumption (85\%), indecent dressing (79\%) and rude behaviour (51\%) are among the attributes of tourists that offend local Emarati culture. Overall, it seems that behaviour more than attitude affects the Emarati perceptions.

The critical views that Emaratis expressed about the social and cultural impacts of tourism did not minimize the importance that Emaratis attach to the desirable economic impacts of tourism. Thus, in spite of their desire for government and other stakeholders to minimize and mitigate the negative sociocultural impacts of tourism, they clearly acknowledge the critical role that tourism plays in the economy of the UAE at large, and Dubai in particular. Table 3 summarizes the views expressed on the economic importance of tourism.

Table 3 shows that more than $60 \%$ of respondents think that Dubai is too dependent on tourism. Interestingly though, half $(51 \%)$ of the respondents believe that Dubai's economy would still be strong without tourism. This 
indicates that most respondents believe Dubai can survive without tourism, hence their recommendation in this study that Dubai invests more in diversifying its economy. Disaggregated by gender, $73 \%$ of the females believed that Dubai is too dependent on tourism, as opposed to only $45 \%$ of males. As for whether tourism was the main factor in Dubai's prosperity, the views were mixed as is evident in Table 3 in the fairly even split between those who agree and those who disagree with the proposition.

Another angle of criticism is the equitability of the dividends of tourism. The survey respondents addressed this issue in their responses to propositions on who benefits the most from tourism. Quite significant in Table 3 is that $55 \%$ of the respondents believed that expatriates, and not Emaratis, reap most of the benefits of tourism. Interestingly, more respondents (43\%) believe that government benefits more from tourism than private businesses. Within the private tourism industry, however, Emaratis fair worse than expatriates in enjoying the dividends of tourism, which may become grounds for anti-tourism sentiments.

The recognition of the economic benefits did not conceal the commercialism of tourism. This raises the issue of the authenticity of the artefacts, activities or events and services sold to tourists as part of Emarati culture, which foreshadows any practical effort to showcase the genuine culture. Table 4 is a summary of the views expressed by the survey respondents on the commercialization and 'trinketization' of tourism at the expense of local culture.

Table 4: $\quad$ Country image and authenticity.

\begin{tabular}{|c|c|c|c|c|}
\hline Question & Agree & Disagree & Neither & $\begin{array}{l}\text { Don't } \\
\text { know }\end{array}$ \\
\hline \multicolumn{5}{|l|}{ Authenticity } \\
\hline $\begin{array}{l}\text { There is no authentic traditional market } \\
\text { for tourists in Dubai }\end{array}$ & $33.65 \%$ & $49.04 \%$ & $9.62 \%$ & $7.69 \%$ \\
\hline $\begin{array}{l}\text { Belly dancing does not show real Emarati } \\
\text { culture }\end{array}$ & $88.46 \%$ & $2.88 \%$ & $3.85 \%$ & $4.81 \%$ \\
\hline $\begin{array}{l}\text { Only the building of Souq Medinat } \\
\text { Jumeirah is an authentic replica of a } \\
\text { traditional market }\end{array}$ & $43.27 \%$ & $24.04 \%$ & $8.65 \%$ & $24.04 \%$ \\
\hline \multicolumn{5}{|l|}{ Presentation of Culture } \\
\hline $\begin{array}{l}\text { Local culture is not well presented to } \\
\text { tourists in many places in Dubai }\end{array}$ & $31.73 \%$ & $47.12 \%$ & $13.46 \%$ & $7.69 \%$ \\
\hline $\begin{array}{l}\text { The artefacts sold in most markets do not } \\
\text { represent local craft and culture }\end{array}$ & $59.62 \%$ & $18.27 \%$ & $12.50 \%$ & $9.62 \%$ \\
\hline $\begin{array}{l}\text { Dancing the Ayyalah/Liwa/Khayali } \\
\text { /Youla does not show real Emarati culture }\end{array}$ & $16.35 \%$ & $73.08 \%$ & $4.81 \%$ & $5.77 \%$ \\
\hline \multicolumn{5}{|l|}{ Overall Image } \\
\hline $\begin{array}{l}\text { Tourism in Dubai only shows modern } \\
\text { Dubai and not local Emarati culture }\end{array}$ & $47.12 \%$ & $38.46 \%$ & $11.54 \%$ & $2.88 \%$ \\
\hline $\begin{array}{l}\text { Shopping malls are the most popular } \\
\text { tourist attractions in Dubai }\end{array}$ & $66.35 \%$ & $18.27 \%$ & $8.65 \%$ & $6.73 \%$ \\
\hline
\end{tabular}


Table 5: Views on addressing tourism in Dubai in the future.

\begin{tabular}{ccccc} 
Question & Agree & Disagree & Neither & $\begin{array}{c}\text { Don't } \\
\text { know }\end{array}$ \\
\hline \hline Government Involvement & & & & \\
\hline $\begin{array}{c}\text { Government should provide the tourism } \\
\text { services, not the private sector }\end{array}$ & $67.31 \%$ & $17.31 \%$ & $5.77 \%$ & $9.62 \%$ \\
\hline $\begin{array}{c}\text { Government should control tourism to } \\
\text { respect Emarati culture more than it is } \\
\text { now doing }\end{array}$ & $84.62 \%$ & $6.73 \%$ & $0.96 \%$ & $7.69 \%$ \\
$\quad \begin{array}{c}\text { Having More Tourism } \\
\text { Government should invest more in } \\
\text { industry and less in tourism }\end{array}$ & $67.31 \%$ & $13.46 \%$ & $12.50 \%$ & $6.73 \%$ \\
\hline $\begin{array}{c}\text { I would not like to see more tourism in } \\
\text { Dubai }\end{array}$ & $40.38 \%$ & $17.31 \%$ & $13.46 \%$ & $28.85 \%$ \\
\hline
\end{tabular}

The final set of propositions posed to the respondents has to do with actions or initiatives by which the main stakeholders in tourism planning and management can address the negative impacts of tourism on Emarati culture. These propositions are shown in Table 5 .

Quite interesting from Table 5 is that most (67\%) of the respondents would like to see the government play a more active role in providing tourism services than the private sector. In the same breadth, a very strong majority $(85 \%)$ would like to see the government control tourism through regulations and laws to respect Emarati culture, beyond what is obtained currently. Only $40 \%$, a weak majority, would like to see more tourism in Dubai, leading to the suggestion by a good majority (68\%) that the government should invest more in industry and less in tourism.

\subsection{Secondary data}

Secondary data gives further insight to the Emaratis frustration with the economic side of tourism. Emaratis have little employment opportunities in the private sector, they are being discriminated against by expatriates and even the very little that do get employed are being forced to resign due to cultural issues. According to the 2005 census, the Western expatriates get up to three times as much remuneration in employment than Emaratis. When comparing the actual numbers obtained through secondary data sources, it seems that their concerns are valid. On the other hand, they feel that their cultural values are being ignored and in many cases purposely offended. While Emaratis do believe that much can be learned by both parties, limited contact stands in the way. A total of 400 nationals work in the entire industry, which employs thousands of people [31], hence real contact would be near nil, regardless of the quality of such contact.

Public media and newspapers give some insight. In addition to general press releases and news clips, there has been some investigative journalism work. An article in the Gulf News recently showed that despite there is a growing job 
market in the UAE, the expatriates occupy $99 \%$ of private sector jobs and $91 \%$ of government sector jobs [32]; it stated that the unemployment rate among nationals is $13 \%$, including only those registered with Tanmia [32], the local government organization that is specialized in reducing unemployment. The article continued to stress that it is expected that by 2020 UAE nationals will account for less than 4\% [32]. It must also be noted that in the UAE, the jobs provided by tourism account for only $1 \%$ of all the employment opportunities [8]. The same article, quoting Jasim Al Ali, a specialist at the Human Resources Department of Dubai Municipality, stated that $10 \%$ of the UAE nationals resign per year due to social and cultural factors. Quoting a research by the specialist, the reasons for this low participation of nationals in the private sector is due to: private sector's business model is largely dependent on low wage jobs; there is a lack of understanding of the cultural barriers; there is a lack of opportunity for training and development for nationals; and negative stereotypes of UAE nationals held by private sector employers [32].

In another article by Dia Hadid [33], it is stated that the UAE job market creates 300,000 jobs per year while there are 15,000 nationals that are added to the unemployment numbers annually [33]. One of the major reasons for that, as per people interviewed by the article, is that there is no job security in the private sector and that employees are highly abused. The article stresses the language and cultural barriers between nationals and the private sector job market [33].

The slow process of political change was challenged by Ebtisam Al Katbi, Associate Professor of Political Science at the UAE University, who was outspokenly in favour of democratic reform: "At present there is a deficient citizenship for the nationals in the UAE. People are loyal to the country but they feel marginalised. They are not integrated and are excluded from decision making" she said [34]. This compares to Daher's [8] interview of local taxi drivers and shop owners in Aqaba, Jordan, that said that they feel the city is no longer theirs due to the government's favouring of tourists.

Smith and Krannich [19] also argue that in many cases, the concerns of the residents seem to be associated with population growth issues since highamenity values such as recreation amenities attract immigrants as well as tourists. In the case of Dubai, high expatriate numbers has already caused many problems on many levels and the secondary data contends that within the next ten years the numbers of Emaratis would be less than $10 \%$ while national identity is already a problem [35]. In a 2008 survey conducted by Al-Khaleej local newspaper, citizens interviewed expressed concerns about the negative impacts on culture, religion and language [35]. On the other hand, some locals are taking some action where possible; an example of such is a sign that was put up on the doors of the Mall of the Emirates by the local owner regarding decency in dress and behaviour [36, 37].

Al Mahadin and Burns [10] explain the relationship between the Orientalist view of the Westerners towards the Arab world and images given to Arab countries as exemplified through travel and tourism brochures. They argue that brochures, travel documentation and photographs are designed to evoke such perceptions. The discourse of Arabia and the Middle East is firmly set in 
exoticism and Orientalism $[8,10,38]$. They contend that in the case of the Arab World, the basis of these "images and ideologies used and expressed, preperceptions, knowledge and pseudo-knowledge, of countries and cultures" is shaped before travelling, and it in turn shapes the tourists' perceptions and prejudices during their stay [10]. They show that most images portrayed through tourism literature symbolise backwardness, oppression and inferiority (veils, camels, 'timeless' (thus backward) tribal people). They are used as icons of tourism in order to influence tourists' travel decisions and perceptions about the countries. Such portrayals of the Arab Muslim world have a damaging impact on promoting realistic ideas about the region, and in effect the discourse used by the travel trade is a form of post-Orientalism [10]. In the same sense, Daher [8] agrees in his criticism of the Euromed Partnership and argues that most Euromed initiatives adopt a digital representation of space, heritage, and tourism with minimal physical effects on the ground yet with serious socio-political and ideological consequences [8].

Last but not least, Dan Stoenescu [39] mentions sex tourism. During the past two decades, there have emerged some centres of prostitution in the Middle East, the most important of which is Dubai $[28,39]$. Despite prostitution being illegal, Dubai has become an international prostitution hub since its economy is based on tourism and trading. The prostitution networks here are very cosmopolitan with prostitutes from Russia, Ethiopia, Uganda, Philippines, Pakistan, India, Morocco and even the UK [39].

\section{Conclusions}

From the previous analysis, there seems to be general negative perceptions related to the following:

- Economy: Emaratis feel that they are too dependent on tourism; dependence increases the negative impacts [19]. In addition, Emaratis feel that they are not the ones benefiting financially from tourism, declaring that expatriates are the ones that do.

- Respect: Emaratis feel that their culture and beliefs are not respected, mainly through tourist behaviour exemplified by consumption of alcohol and what is perceived in local culture as indecent dress. Other factors were not included in the survey in order not make it too long such as Public Displays of Affection (PDA) and prostitution, but secondary data has showed Emaratis' disapproval of them.

- The Demonstration Effect: despite it being criticised and found to be patronising to local communities by some scholars and authors, it seems that Emaratis conceive it as a fact of life, the interesting finding that the younger generations were the most agreeing to the fact that they imitate tourists shows that while they oppose to it, they still practice it.

Tourism in Dubai is still a new industry compared to worldwide tourism. However, it seems that the residents already have some negative perceptions and attitudes; they are currently openly expressing irritation as shown not only in the survey results but also through the secondary data sources. This can be a 
dangerous attitude as much of the projects are still in the physical development phase, which means that more tourists are expected in the future. The early irritation status compared to other regions can be explained by the unique demographic structure of the UAE where the Emaratis, despite being the nationals, have been outnumbered by expatriates at a rate of five to one. Most expatriates have only a limited connection with Dubai and have come on a temporary basis. While they are not technically tourists, they both act and feel as foreigners. The existence of expatriates precedes tourism by many years and while their percentage was not as high twenty or twenty five years ago, their existence may have initiated the current perceptions before the actual initiation of tourism.

\section{References}

[1] About Dubai; The Official Portal of Dubai Government. Accessed online through the World Wide Web at: http://www.dubai.ae.

[2] USA Library of Congress Federal Research Division. http://lcweb2.loc.gove/frd/cs/profiles/UAE.pdf.

[3] UAE Interact, 16th February 2008. Tourism Arrivals on the Rise in Dubai. Accessed electronically on 7th April 2008 at: http://uaeinteract.com/docs/ Tourist arrivals on the rise in Dubai/28648.htm.

[4] UAE Interact, $\overline{9}$ th $\overline{\text { March }} 2 \overline{0} 08$. Tourism adds $22.6 \%$ to UAE economy. Accessed electronically n 7th April 2008 at: http://uaeinteract.com/docs/ Tourism_adds_22.6_to_UAE_economy/29015.htm.

[5] Jafari, J. The Socio-Economic Costs of Tourism to Developing Countries. Annals of Tourism Research, 1:227-62. 1974.

[6] Mowforth, M. and Munt, I. Tourism and Sustainability: Development and New Tourism in the Third World. London and New York: Routledge. 2005.

[7] Higgings-Desbiolles, F. Hostile Meeting Grounds: Encounters between the Wretched of the Earth and the Tourist through Tourism and Terrorism in the 21st Century. In Tourism and Politics: Global Frameworks and Local Realities. Bruns P. and Novelli, M. (ed.) 2007. Oxford and Amsterdam: Elsevier. 2007.

[8] Daher, R. F. (ed.) Tourism in the Middle East: Continuity, Change and Transformation. Clevedon, UK: Channel View Publications. 2007.

[9] Tucker, H. and Hall, M. Conclusion. In Tourism and Postcolonialism: Contested Discourses, Identities and Representations. Hall, and Tucker (ed.) 2004. London and New York: Rutledge. 2004.

[10] Al Mahadin, S and Burns, P. Visitors, Visions and Veils: The Portrayal of the Arab World in Tourism Advertising. In Tourism in the Middle East: Continuity, Change and Transformation. Clevedon, UK: Channel View Publications. 2007.

[11] Ap, J. Residents' Perceptions on Tourism Impact. Annals of Tourism Research, 19(4): 665-690. 1992. 
[12] Allen, L.R.; Hafer, H. R'; Long, R and Perdue, R.R. Rural Residents' Attitudes Towards Recreation and Tourism Development. Journal of Travel Research, 27(1):27-33. 1993.

[13] Ap, J and Crompton J.L. Residents Strategies for Responding to Tourism Impacts. Journal of Travel Research, 32(1):47-50. 1993.

[14] Tosun, C. Host Perceptions of Impacts: A Comparative Tourism Study. Annals of Tourism Research, 29(1): 231-253. 2002.

[15] Orbasli, A. The 'Islamic' City and Tourism: Managing Conservation and Tourism in Traditional Neighbourhoods. In Daher, R. F. (ed.) 2007. Tourism in the Middle East: Continuity, Change and Transformation. Clevedon, UK: Channel View Publications. 2007.

[16] Homa, D. Touristic Development in Sinai, Egypt: Bedouin, Visitors, and Government Interaction. In Tourism in the Middle East: Continuity, Change and Transformation. Daher, R. F. (ed.) 2007. Clevedon, UK: Channel View Publications. 2007.

[17] Akis, S.; Peristianis, N.; and Warner, J. Residents' Attitudes to Tourism Development: the Case of Cyprus. Tourism Management, 17(7): 481-494. 1996.

[18] Gursoy, D; Jurowski, C. and Uysal, M. Resident Attitudes: A Structural Modeling Approach. Annals of Tourism Research, 29(1): 79-105. 2002.

[19] Smith, M and Krannich, R. Tourism Dependence and Resident Attitudes. Annals of Tourism Research, 25(4): 783-802. 1998.

[20] Teye, F.; Sonmez, S. F.; and Sirakaya, E. Residents' Attitudes Toward Tourism Development. Annals of Tourism Research, 29(3): 668-688. 2002.

[21] Brunt, P. and Courtney, P. Host Perceptions of Sociocultural Impacts. Annals of Tourism Research, 26(3): 493-515. 1999.

[22] Singh, S., Timothey, J., and Dowling, R. K. (ed) Tourism in Destination Communities. Oxford and Cambridge, MA: CABI Publishing. 2003.

[23] King, B.; Pizam, A.; Milman, A. Social Impacts of Tourism: Host Perceptions. Annals of Tourism Research, 20: 650-665. 1993.

[24] Fisher, D. A Colonial Town for Neocolonial Tourism. In Tourism and Postcolonialism: Contested Discourses, Identities and Representations. Hall, M. and Tucker, C (ed.) London and New York: Rutledge. 2004.

[25] Fagence, M. Tourism and Local Society and Culture. In Tourism in Destination Communities. Singh, S., Timothey, J., and Dowling, R. K. (ed) 2003. Oxford and Cambridge, MA: CABI. 2003.

[26] Engelhardt, R. Preface. In Case Study on the Effects of Tourism on Culture and the Environment by Soubert, S. and Hay, S. L. for UNESCO. UNESCO Principal Regional Office for Asia and the Pacific: Bangkok. 1995.

[27] Besculides, A.; Lee, M. and McCormick, P. Residents' Perceptions of the Cultural Benefits of Tourism. Annals of Tourism Research, 29(2): 303319. 2002.

[28] Hazbun, W. New Agenda for Tourism Development in the Arab World. A paper for "The New Agenda: The Arab World in the 21st Century" conference League of Arab States, Cairo, Egypt, March 2003. 
[29] Henderson, J. Tourism and British Colonial Heritage in Malaysia and Singapore. In Tourism and Postcolonialism: Contested Discourses, Identities and Representations. Hall, M. C and Tucker, C (ed.) 2004. London and New York: Routledge. 2004.

[30] Pizam, A., Newmann, Y. \& Reichel, A. Tourist Satisfaction: Uses and Misuses. Annals of Tourism Research, 5(3): 314-322. 1978.

[31] Ezz Al Deen, M. Tourism Sector to Step Up Eemiratisation. Gulf News, accessed through the World Wide Web on 7th April 2008 at: http://archive.gulfnews.com/indepth/labour/ Emiritisation/10052972.html. 12 th July 2006.

[32] Ahmad, A. Expats make up 99\% of private sector staff. Gulf News, accessed via the World Wide Web on 7th April 2008 at: http://www.gulfnews.com/nation/Employment/ 10203548.html. 7th April 2008

[33] Hadid, D. Easier Work Culture Lures. Gulf News, accessed through the World Wide Web on 7th April 2008 at: http://archive.gulfnews.com/indepth/labour/Emiritisation/10037860.html. 5th May 2006.

[34] Mathew, F. Gulf States Resist Political Change. Gulf News, accessed electronically through the World Wide Web on 7th April 2008 at: http://archive.gulfnews.com/articles/08/04/05/10203072.html. 5th April 2008.

[35] Okel, H. National Identity Year, Where to Start? (Series) Al Khaleej Newspaper (Arabic), Sharjah: Dar Al Khaleej. 5th to 23rd January 2008.

[36] Khan, M. N. Mall of the emirates: No kissing please, you are at a mall. Xpress, accessed electronically at: http://www.xpress4me.com/articles/08/02/06/20005677.html. 7th Feb 2008.

[37] Sinclair, Z. Mall of the Emirates Calls to observe Decency Code. Al Khaleej Times, accessed electronically at: http://www.zawya.com/Story. cfm/sidZAWYA20080222071914/SecMain/pagHomepage/chnAll\%20Regi onal\%20News/obj2A17E941-F5E0-11D4-867D00D0B74A0D7C/. 22nd Feb 2008.

[38] Sardar, Ziauddin. Orientalism, Buckingham, U.K. and Philadelphia: Open University Press. 1999

[39] Stoenescu, D. Globalising Prostitution in the Middle East. in International Relations and Globalisation in the Middle East, Dan Stoenescu and Dana Pleşa, Semne Publishing House, Bucharest, pp.266-283 2005. 